\title{
Genetic diversity of Epimedium elatum (Morren \& Decne) revealed by RAPD characterization
}

\author{
Sajad Ahmad Lone',3, Parvaiz Hassan Qazi ${ }^{13}$, Suphla Gupta ${ }^{2,3 *}$ \\ 'Biotechnology division, CSIR-Indian Institute of Integrative Medicine, Srinagar, 190005, India, ${ }^{2}$ Plant Biotechnology \\ division, CSIR-Indian Institute of Integrative Medicine, Jammu-180001, India, ${ }^{3}$ Academy of Scientific and Innovative \\ Research (AcSIR), Anusandhan Bhawan, New Delhi, 110001, India
}

Received: September 15, 2017 Accepted: December 28, 2017 Published: January 14, 2018

*Corresponding Author: Suphla Gupta, Plant Biotechnology division, CSIR-Indian Institute of Integrative Medicine, Jammu-180001, India.

Email Id: suphlabg@gmail.com KEYWORDs: Epimedium elatum, icariin, accession, northwestern himalayas, genetic diversity

\begin{abstract}
Epimedium elatum (Morren \& Decne) is a rare perennial monotypic medicinal herb of Berberidaceae family, endemic to high altitude shady coniferous forests of Northwestern Himalayas in India. Traditionally, it has been used in local health care system for treatment of many ailments. In the present study, a total of ten RAPD markers were used for assessment of genetic diversity in twenty accessions of E. elatum, collected from diverse ecozones in Jammu and Kashmir. Ten primers amplified a total of 100 polymorphic bands with average of 10 bands per assay unit. Primer OPO-07 generated maximum number of bands (15) \& produced highest polymorphic information content (0.39), marker index (5.96) and resolving power (8.9), thereby distinguishing E. elatum genotypes. The study showed moderate level of genetic polymorphism in twenty accessions of E. elatum. RAPD data set revealed association between genetic diversity and eco-geographic distribution of most E. elatum genotypes, and thereby proved useful tool for their genetic/molecular characterization. There is an urgent need for developing quick conservation strategies to save its natural germplasm from extinction in the Northwestern Himalayas.
\end{abstract}

\section{INTRODUCTION}

Epimedium elatum (Morren \& Decne) is a perennial medicinal herb (Fig.1), endemic to high altitude shady coniferous forests of Northwestern Himalayas in India and Pakistan [1-3]. This species was first reported from Kashmir Himalayas by European botanists [4-7] during their botanical expeditions in India. The plant has characteristic 'three branches and nine leaves' morphological pattern, common to most Epimedium species. Traditionally, it has been used in treating many ailments like toothaches, bone-joint and kidney disorders [8]. E. elatum contains significant amount of key phytochemicals (Fig. 2) like epimedin B, epimedin $\mathrm{C}$, icariin and icariside-I [8-11], which are known to possess key pharmaceutical properties like phosphodiesterase-5 inhibition (aphrodisiac role), anti-osteoporosis, antioxidant and anticancer activities [12]. Previously, extracts or chemical components from E. elatum have been assessed for antioxidant [3 and 10] antimicrobial and anti-diabetic activities [13]. However, genetic diversity of E. elatum was unreported and determination of same is essential for conserving rare medicinal plants [14-17].

Genetic diversity assessments bring forth genetic polymorphism existing in a population. It may or may not bring about changes in the morphological, biochemical, physiological or DNA sequences [14]. These genetic changes may be monitored by the presence or absence of an allele at a locus. New alleles can appear at each generation by spontaneous mutation due to DNA replication errors or mutagen-induced DNA damage or recombination events [15]. Knowledge of genetic diversity in a population helps in better adaptability of a species. For assessing, preserving and cataloguing a population, its genetic assessment is pivotal [16]. An understanding about genetic diversity patterns is important in estimating evolutionary pathways and in predicting future risk [17]. The process becomes more pertinent in case of endangered and rare species, as it helps in prioritization of sites and man-agement choices for future conservation programmes. Molecular markers are important in assessing genetic diversity at the gene level in determining allele frequencies to nucleotide 
level [18]. Literature reports that RAPD molecular markers have been used for determining the genetic diversity in Epimedium species [19-23]. Assessment of genetic diversity in E. elatum was hitherto unreported and hence present study investigated same for identification of its elite genotypes and their subsequent conservation by concerned stakeholders involved in medicinal plant research in North India.

\section{MATERIALS AND METHODS}

\section{Study Area and Experimenting Material}

The climate of Kashmir Himalayas in Jammu \& Kashmir State of India ranges between temperate and sub-alpine and it lies

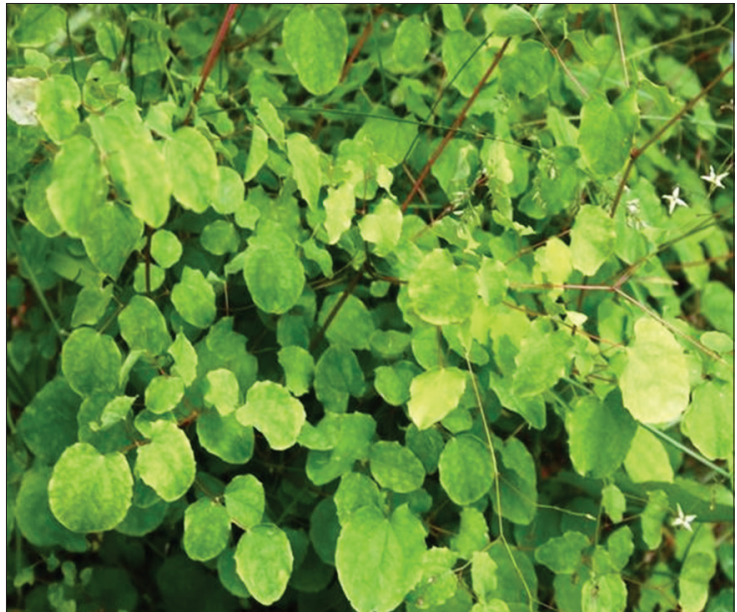

Figure1: Epimedium elatum (Morr \& Decne.), unexplored medicinal herb of Northwestern Himalayas in India between $33^{\circ} 20-34^{\circ} 54^{\prime} \mathrm{N}$ latitudes and $73^{\circ} 55^{\prime}-75^{\circ} 3^{\prime}$ E E longitudes in Northwestern Himalayas. It is home to rich and diverse medicinal plants, known globally for their pharmaceutical properties. Based on reported locations in floras, herbarium records, research articles and internet searches, extensive investigation was made in Kashmir Himalayas. The planting material was collected from twenty different ecozones and kept in ziplock bags at low temperature in laboratory for DNA extraction. The extracted DNA was stored at $-80^{\circ} \mathrm{C}$ until PCR optimization with RAPD markers. All twenty accessions were identified by taxonomists at Kashmir University herbarium (KASH) \& CSIR-IIIM Jammu herbarium (RRLH) respectively. The altitude of the representative sites ranged from $1800 \mathrm{~m}$ to $3400 \mathrm{~m}$ asl and geographical distance ranged between $5.5 \mathrm{~km}$ to $250 \mathrm{~km}$ (Table.1).

\section{DNA Extraction for Molecular Characterization}

Fresh young leaves were subjected to the several DNA extraction protocols for high quality DNA. Two extraction protocols with some modifications influenced the yield and quality of genomic DNA from the leaves of E. elatum viz; CTAB based method of Doyle \& Doyle (1987) and Porebski et al (2009) [24, 25]. The quality of isolated DNA was checked on agar-ose gel and quantified spectroscopically by measuring light absorption at $260 \mathrm{~nm}$. Nucleic acid purity was checked by determining absorption at a wavelength of 230 and $280 \mathrm{~nm}$, respectively and concentration of DNA was determined in terms of $\mathrm{ng} / \mu \mathrm{l}$ for twenty accessions (Table 2). The deviation from the value of 1.80 at A260/A280 $\mathrm{nm}$ absorbance ratio was used as an indicator of RNA and protein contamination in the extracted genomic DNA.

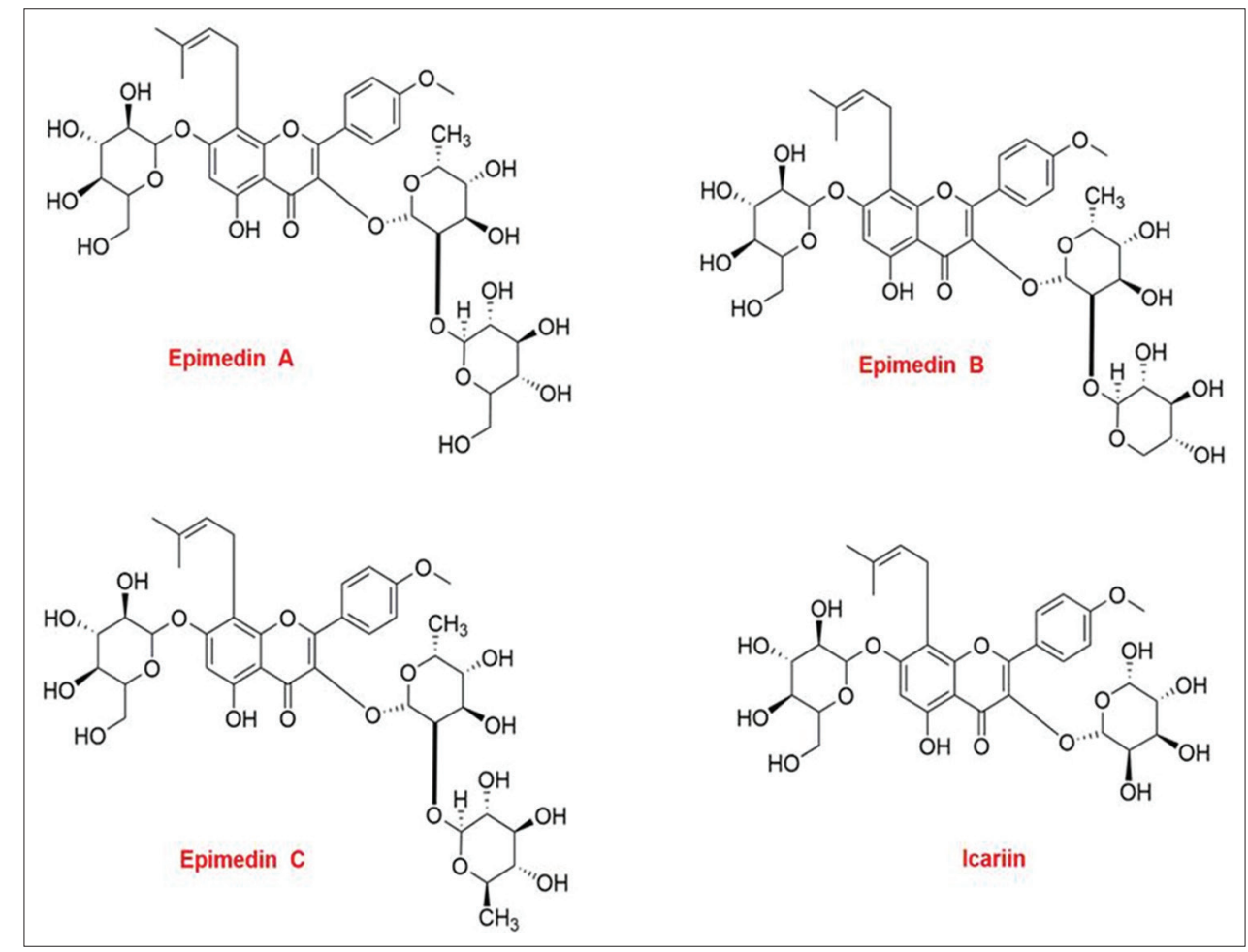

Figure 2: Four major chemotaxonomic markers found in E. elatum 
Table 1: Passport data of E pi medi um el atum collected from Kashmir Himalayas

\begin{tabular}{|c|c|c|c|c|c|c|c|}
\hline S.No & Collection Site & Code & Latitude & Longitude & $\mathrm{RRLH}^{\#}$ & $\mathrm{KASH}^{\$}$ & District \\
\hline 1 & Gulmarg & $G L$ & $34.02^{\circ}$ & $74.22^{\circ}$ & 22304 & 2094 & Baramulla \\
\hline 2 & Babareshi & BR & $34.03^{\circ}$ & $74.23^{\circ}$ & 22306 & 2099 & Baramulla \\
\hline 3 & Drang & DR & $33.55^{\circ}$ & $74.29^{\circ}$ & 22305 & 2105 & Baramulla \\
\hline 4 & Dangarpora & $D G$ & $34.05^{\circ}$ & $74.32^{\circ}$ & 22308 & 2103 & Baramulla \\
\hline 5 & Boniyar & BY & $34.15^{\circ}$ & $74.21^{\circ}$ & 22307 & 2107 & Baramulla \\
\hline 6 & Yusmarg & YS & $33.49^{\circ}$ & $74.40^{\circ}$ & 22310 & 2101 & Budgam \\
\hline 7 & Dodipathri & DP & $33.53^{\circ}$ & $74.34^{\circ}$ & 22309 & 2095 & Budgam \\
\hline 8 & Naranag & NAR & $34.21^{\circ}$ & $74.58^{\circ}$ & 22303 & 2102 & Ganderbal \\
\hline 9 & Gagangir & $G G$ & $34.17^{\circ}$ & $75.12^{\circ}$ & 22314 & 2109 & Ganderbal \\
\hline 10 & Dachigam & DGM & $34.08^{\circ}$ & $75.02^{\circ}$ & 22312 & 2100 & Srinagar \\
\hline 11 & Pahalgam & PGM & $34.00^{\circ}$ & $75.18^{\circ}$ & 22319 & 2093 & Anantnag \\
\hline 12 & Kokernag & KNG & $33.34^{\circ}$ & $75.17^{\circ}$ & 22311 & 2092 & Anantnag \\
\hline 13 & Verinag & VNG & $33.32^{\circ}$ & $75.14^{\circ}$ & 22320 & 2108 & Anantnag \\
\hline 14 & Khillanmarg & KMG & $34.02^{\circ}$ & $74.21^{\circ}$ & 22315 & 2104 & Baramulla \\
\hline 15 & Chaknala & CNG & $34.37^{\circ}$ & $74.51^{\circ}$ & 22316 & 2097 & Bandipora \\
\hline 16 & Sheikhpora & SPG & $34.35^{\circ}$ & $74.59^{\circ}$ & 22317 & 2096 & Bandipora \\
\hline 17 & Kanzalwan & $K Z G$ & $34.38^{\circ}$ & $74.42^{\circ}$ & 22318 & 2098 & Bandipora \\
\hline 18 & Badwan & $B D G$ & $33.39^{\circ}$ & $74.46^{\circ}$ & 22321 & 2106 & Bandipora \\
\hline 19 & Hirpora & $\mathrm{HP}$ & $33.39^{\circ}$ & $74.57^{\circ}$ & 22322 & 2090 & Shopian \\
\hline 20 & Aharbal & $A B$ & $33.38^{\circ}$ & $74.74^{\circ}$ & 22313 & 2091 & Kulgam \\
\hline
\end{tabular}

\#Acronym for CSIR-IIIM Jammu herbarium, ${ }^{\$}$ Acronym for Kashmir University herbarium

\section{PCR Optimization}

For the successful amplification of RAPD markers in Epimedium elatum, different PCR conditions and cycling parameters were tested. The concentration of various components of master mix such as primer, dNTPs, 10x Taq buffer, Taq DNA polymerase, and the template were optimized for PCR analysis. A total of 10 RAPD primers were screened based on the primer set published by the Biotechnology Laboratory, University of British Columbia, Canada (UBC) and the RAPD studies on Podophyllum hexandrum [26-29].

The amplifications were performed in a thermal cycler (ABI Geneamp 9700, Thermo Scientific, USA) and for RAPD fingerprinting; annealing temperature was also standardized for every primer. The amplification was carried out in a reaction volume of $20 \mu \mathrm{l}$ with standardized conditions. Each primer was amplified in triplicate to confirm reproducibility. PCR was carried out for 35 cycles, under the following conditions: $95^{\circ} \mathrm{C}$ for $5 \mathrm{~min}, 92^{\circ} \mathrm{C}$ for $60 \mathrm{sec}$, (screening) $32-34^{\circ} \mathrm{C}$ for $1 \mathrm{~min}, 72^{\circ} \mathrm{C}$ for $2 \mathrm{~min}, 72^{\circ} \mathrm{C}$ for $7 \mathrm{~min}$ and 35 cycles.

The amplified PCR product were separated on $1.4 \%(\mathrm{w} / \mathrm{v})$ agarose gel with IX TAE buffer and stained with ethidium bromide $(0.5 \mu \mathrm{g} / \mathrm{ml}$, Sigma, USA). Electrophoresis was carried out till all the amplified DNA fragments were clearly resolved. Fermentas Gene Ruler ${ }^{\mathrm{TM}}$ (100 bp plus ladder) was used marker to determine the size of the amplified products. DNA fragments were visualized under UV light and documented with the gel documentation imaging system (GelDoc- Syngene Bio imaging System UK.).

\section{Scoring of Bands and Data Analysis}

The PCR-amplified fragments were scored in a binary quantitative matrix as 1 (present) and 0 (absent) for all the primers. Weak bands of negligible intensity and smeared bands were excluded. The genetic diversity parameters like percentage of polymorphism, Curr Bot • $2018 \bullet$ Vol 9
Table 2: Quantification of DNA concentration by UV spectrophotometry (Nanodrop)

\begin{tabular}{lllccc}
\hline S.No & Accessions & Code & $\begin{array}{c}\text { Conc ng/ } \\
\mu l\end{array}$ & $260 / 280$ & $260 / 230$ \\
\hline 1 & Gulmarg & GL & 1386 & 1.97 & 1.37 \\
2 & Babareshi & BR & 514 & 1.81 & 1.42 \\
3 & Drang & DR & 778 & 1.88 & 1.90 \\
4 & Dangarpora & DG & 640 & 1.74 & 1.26 \\
5 & Boniyar & BY-12 & 146 & 1.81 & 1.61 \\
6 & Yusmarg & YS & 995 & 1.87 & 1.63 \\
7 & Dodipathri & DP & 1779 & 1.82 & 1.32 \\
8 & Naranag & NAR & 657 & 1.88 & 1.59 \\
9 & Gagangir & GG & 936 & 1.80 & 1.59 \\
10 & Dachigam & DGM & 326 & 1.98 & 1.09 \\
11 & Pahalgam & PGM & 1609 & 1.91 & 1.63 \\
12 & Kokernag & KNG & 827 & 1.92 & 1.69 \\
13 & Verinag & VNG & 780 & 1.80 & 1.12 \\
14 & Khillanmarg & KMG & 994 & 1.93 & 1.65 \\
15 & Chaknala & CNG & 609 & 1.88 & 1.00 \\
16 & Sheikhpora & SPG & 452 & 1.80 & 0.96 \\
17 & Kanzalwan & KZG-3 & 219 & 1.78 & 1.15 \\
18 & Badwan & BDG & 825 & 1.74 & 0.39 \\
19 & Hirpora & HP & 1635 & 1.88 & 1.37 \\
20 & Aharbal & AB & 1132 & 1.90 & 0.96 \\
\hline
\end{tabular}

total number of bands (TB) amplified/primer; total numbers of polymorphic bands, total number of monomorphic bands were calculated for all the 10 primers. Besides, genotypic data was assessed for polymorphic information content [30], marker index [31] and resolving power [32].The scored binary data generated was used for the construction of dendrogram by Jaccard's similarity coefficient using NTSYS- pe version 2.02e [33].

\section{RESULTS AND DISCUSSION}

\section{Collection of Epimedium Elatum Genotypes from Diverse Eco-regions}

Distribution of E. elatum was poorly known in Kashmir Himalayas due to lack of research on this medicinal plant. 
Surveying of the Berberidaceace accessions in herbarium of Kashmir University (KASH) provided essential clues for working out its distributional range in valley. Only two specimens of E. elatum were deposited by curator A.R Naqshi around 1970s. He had collected them from Harwan forests. In late 1980s, a few Indian Botanists like Gurcharan Singh reported and documented its existence in 'Forest flora of Srinagar and plants of neighbourhood'. And some had documented its location at Pahalgam ecozone $[34,35]$. But, overall, distributional data on E. elatum was inadequate and documentation of same was needed for developing conservational strategies. In this connection, we surveyed 30 locations in Kashmir Himalayas and collected its accessions from twenty geographical areas (Fig.3). We surveyed 8 districts out of 10 in the valley. Most of the populations of E. elatum were facing severe threats and had small population size [37]. Therefore, this plant needs immediate protection as there are chances of its extinction from many surveyed areas in the Kashmir Himalayas, India.

\section{Modified DNA Extraction Protocol}

Initially, it was difficult to get good quality DNA for RAPD fingerprinting studies in E. elatum genotypes. We tried several DNA extraction protocols and among them, we selected two protocols $[24,25]$ after certain modifications to get quality DNA, prerequisite for DNA fingerprinting studies [36].

\section{Genetic Diversity Characterization by RAPD Markers in E.elatum Genotypes}

In the present study, a total of ten RAPD markers were used for assessment of genetic diversity in twenty accessions of E. elatum. Results obtained are summarized in Table 3. These ten primers amplified a total of 100 polymorphic bands with average of 10 bands per assay unit or marker used. Size of the amplified DNA fragments scored, ranged from 450 to 1600 bp and allele size was estimated visually by comparing with 100 bp plus ladder

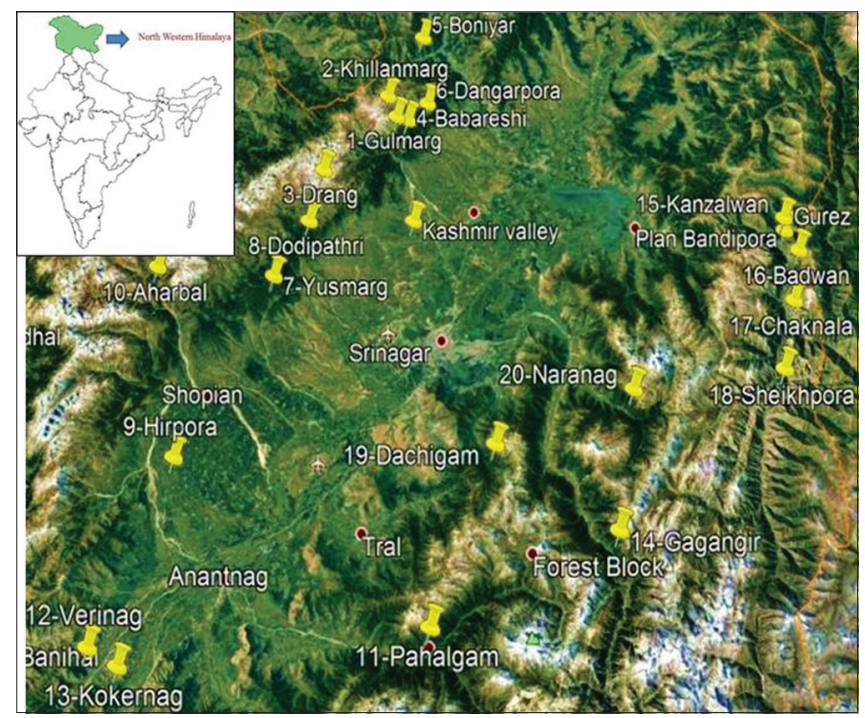

Figure 3: Distributional map of twenty accessions of E.elatum collected from diverse ecogeographical regions of Kashmir Himalayas in India
(Fermentas) on a gel (Fig.4). The largest numbers of alleles were amplified by OPO-07 (15), whereas three primers viz; OPO-01, OPO-06 \& OPO-10 produced minimum of 07 bands each. In order to detect the most effective primers that could distinguish all the cultivars either individually or in combination, three different indices like Polymorphic Information Content (PIC), Markers Index (MI) and Resolving Power (RP) were pragmatic in the present study (Table 3). The utility of a specified marker is ascertained by the level of polymorphism, and its ability to detect multiple polymorphisms [31]. Marker index is one such genetic diversity index of a marker which reveals the discriminatory power of a marker.

Among all the RAPD primers assessed, OPO-07 showed highest MI (5.96), whereas OPO-04 showed lowest MI values (2.05).

Table 3: Genetic diversity parameters for ten RAPD primers used for molecular characterization of twenty accessions of E. elatum

\begin{tabular}{lllllllll}
\hline S.No Primers Sequence & \multicolumn{3}{c}{ TNB NMB NPB PPB } & $\begin{array}{c}\text { PIC } \\
\text { 2fi (1-fi) }\end{array}$ & MI & Rp \\
\hline 1 & OP0-01 GGCACGTAAG & 07 & 0 & 07 & 100 & 0.29 & 2.11 & 2.8 \\
2 & OP0-02 ACGTAGCGTC & 10 & 0 & 10 & 100 & 0.23 & 3.67 & 4.5 \\
3 & OP0-03 CTGTTGCTAC & 08 & 0 & 08 & 100 & 0.28 & 2.64 & 2.7 \\
4 & OP0-04 AAGTCCGCTC & 11 & 0 & 11 & 100 & 0.25 & 2.11 & 4.5 \\
5 & OP0-05 CCCAGTCACT & 14 & 0 & 14 & 100 & 0.19 & 2.28 & 3.3 \\
6 & OP0-06 CCACGGGAAG & 07 & 0 & 07 & 100 & 0.29 & 2.94 & 2.5 \\
7 & OP0-07 CAGCACTGAC & 15 & 0 & 15 & 100 & 0.39 & 5.96 & 8.9 \\
8 & OP0-08 CCTCCAGTGT & 12 & 0 & 12 & 100 & 0.28 & 2.33 & 5.3 \\
9 & OP0-09 TCCCACGCAA & 09 & 0 & 09 & 100 & 0.29 & 2.60 & 3.2 \\
10 & OP0-10 TCAGAGCGCC & 07 & 0 & 07 & 100 & 0.22 & 2.39 & 2.8 \\
\hline
\end{tabular}

TNB: total number of bands, NPB: number of polymorphic bands, NMB: number of monomorphic bands, PPB: percentage of polymorphic bands, PIC: polymorphism information content, MI: marker index, Rp: resolving power

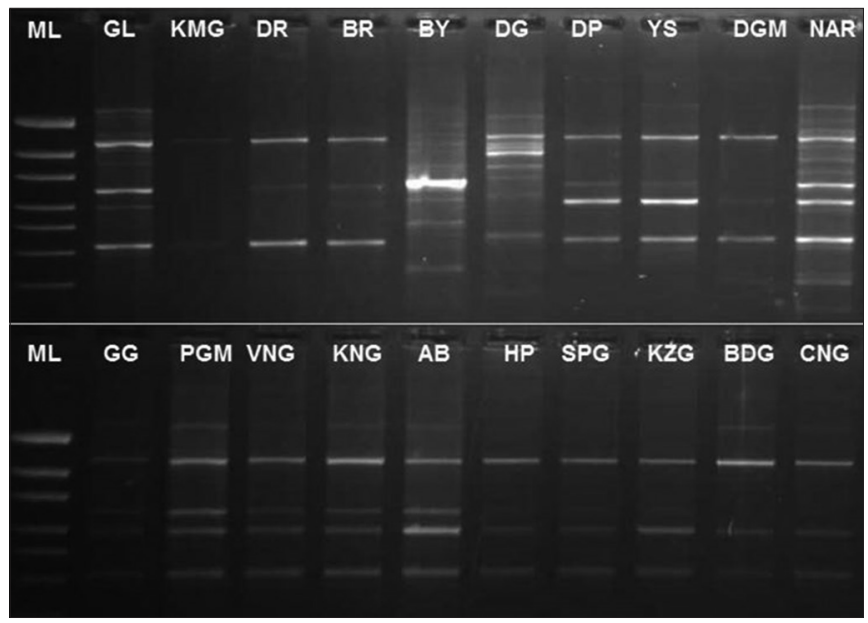

Figure 4: Results of PCR amplification of OPO-05 primer in twenty E.elatum genotypes via RAPD fingerprinting. \{M: DNA ladder (100bp plus]. [Position of gel lanes (1-20) showing twenty accessions; 1-GL (Gulmarg); 2-KMG (Khillanmarg); 3-DR (Drang); 4-BR (Babareshi); 5-BY (Boniyar); 7-DG (Dangarpora); 7-; (Dodipathri) 8-YS (Yusmarg); 9-DGM (Dachigam); 10-NAR (Naranag); 11-GG (Gagangir); 12-PGM (Pahalgam); 13-VNG (Verinag); 14-KNG (Kokernag); 15-AB (Aharbal) 16-HP (Hirpora) 17-SPG (Sheikhpora); 18-KZG (Kanzalwan); 19-BDG (Badwan); 20-CNG (Checknala)] 


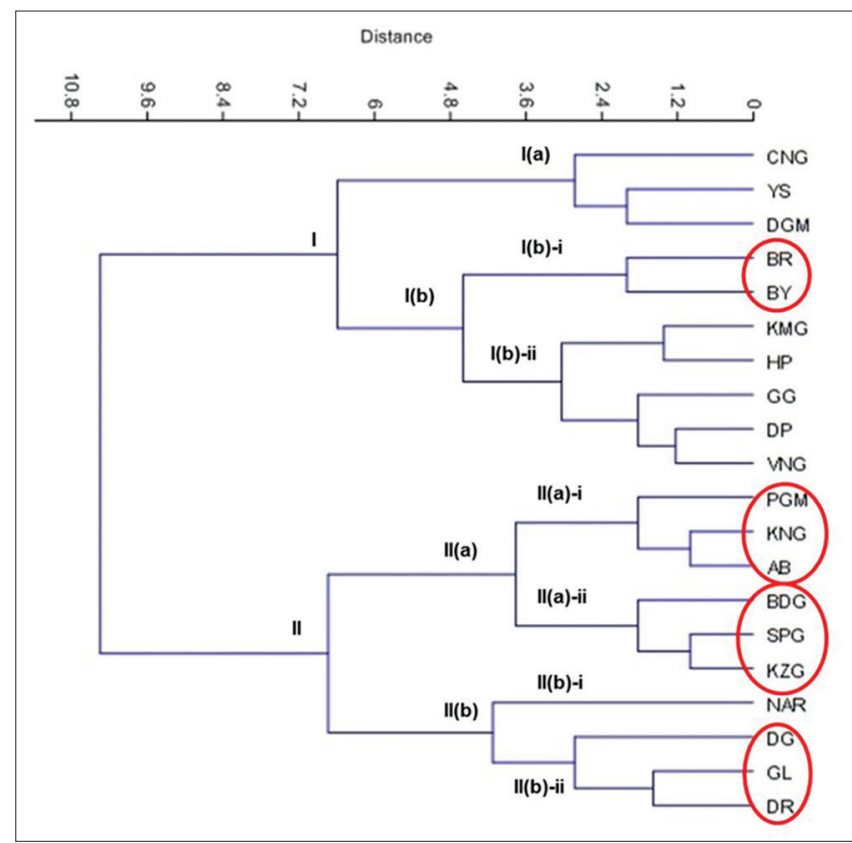

Figure 5: Phylogenetic tree based on RAPD data in twenty accessions of $E$. elatum using UPGMA analysis. (CNG-Checknala Gurez; YS-Yusmarg; DGM-Dachigam; BR- Babareshi BY-Boniyar; KMG-Khillanmarg; HP-Hirpora; GG-Gagangir; DP-Dodipathri; VNG-Verinag; PGM-Pahalgam; KNG-Kokernag; AB-Aharbal; BDG-Badwan Gurez; SPG-Sheikhpora Gurez; KZG-Kanzalwan Gurez;; DR-Drang; NAR-Naranag; DG-Dangarpora; GL-Gulmarg; DR-Drang)

OPO-07 primer showed highest PIC (0.39) values, whereas, OPO-05 produced lowest PIC value (0.19). Highest resolving power was observed for primer OPO-07 (8.9), whereas, lowest value was found in OPO-03 primer (2.7). The average values for each of these genetic diversity parametres were found to be 0.27 (PIC), 2.89 (MI) and 4.05 (Rp) in our study.

All genetic diversity values obtained were lower than our earlier results [3], employing ISSR primers for analysing genetic diversity of E. elatum. On comparing the two marker systems, it was observed that the average number of bands amplified by ISSR fingerprinting was 17.5/primer as compared to RAPD (10). Comparatively, ISSR analysis provided better results than RAPD characterization. However, one RAPD primer OPO-07 was able to distinguish most genotypes of E. elatum at genetic level effectively. The average value of PIC (0.36) and $\mathrm{Rp}(7.2)$ were also higher in ISSR marker system than in RAPD. Our study was in confirmation with many earlier RAPD studies on Epimedium species. Nakai et al. [19] had shown that Epimedium species can be genetically distinguished on the basis of unique RAPD fingerprint. In related studies, RAPD markers aided in solving phylogenetic relationship of Epimedium species by establishing unique fingerprints and consequently showing high genetic diversity [21,22]. Both RAPD \& ISSR molecular markers assisted in the easy genotype characterization of E. elatum. These markers showed moderate to high genetic diversity existing in its different populations.

\section{RAPD based Genetic Relationship among Genotypes}

The genetic relationship between the twenty wild E. elatum accessions was determined by clustering the genotypes using
UPGMA based dendrogram, which phylogenetically classified twenty accessions into two broad clusters (I \& II) with each cluster having ten accessions (Fig.5). Cluster I was further sub-divided into two sub-clusters I(a) \& I(b), with former cluster grouping three accessions (CNG, YS \& DGM) and latter clustering seven accessions in two sub-groups [I(b)-i \& I(b)-ii]. Cluster II was further subdivided into II (a) and II (b) with two sub-clusters [II (b)-i \&II (b)-ii]. Correlation was observed between genotype clustering \& geographical distribution of eleven E. elatum accessions. For example, genotypes collected from Gurez clustered together in dendrogram. Our results are in line with earlier RAPD studies in Epimedium species, where geographic distribution was correlated with dendrogram topology [21-23]. RAPD markers used in the present study revealed representation of the genetic and geographic relationship for most of the E. elatum genotypes. Efficient molecular markers are needed to throw more light on overall genetic characterization of E. elatum in Kashmir Himalayas in India.

\section{CONCLUSIONS}

Epimedium elatum was a neglected species before we initiated a bioprospection of this plant. Recent literature has shown its medicinal potential at par with the officially recognized ingredients of Herba Epimedii, commonly known as Herbal Viagra [38]. The plant has great potential for several future medicinal uses because of its reported pharmacological activities $(9,10, \& 13)$. To get the best efficacy of an herbal product the plant needs to be authenticated. Both RAPD \& ISSR molecular techniques have shown their potential in distinguishing and identifying E. elatum genotypes. They have provided useful information regarding the level of genetic polymorphism in E. elatum collected from geographically diverse regions. Both the marker systems have comparable accuracy in grouping genotypes according to their geographical area. This study will provide valuable evidence for decision making in choosing of markers for future work, characterization of germplasm, breeding of E. elatum germplasm management. This plant needs immediate ex-situ and in-situ conservation in Northwestern Himalayas in India.

\section{ACKNOWLEDGEMENT}

The authors are thankful to director CSIR-IIIM Jammu for providing necessary research facilities for carrying out the study. Acknowledgements are due to University Grants Commission (UGC), New Delhi for providing fellowship and AcSIR cell for academic support.

\section{COMPETING INTERESTS}

The authors declare that they have no competing interests.

\section{REFERENCES}

1. Nasir E, Ali SI. Flora of Pakistan. Berberidaceace. University of Karachi, Karachi. 2005; 87:1-31.

2. Perveen A, Qaiser M. Pollen flora of Pakistan-LXV. Berberidaceae. 
Pakistan Journal of Botany. 2010; 42(1):1-6.

3. Lone SA, Kushwaha M, Wani A, Kumar A, Gupta AP, Hassan QP, Gupta S. Genetic diversity, LCMS based chemical fingerprinting and antioxidant activity of Epimedium elatum Morr \& Decne. Journal of Applied Research on Medicinal and Aromatic Plants. 2017; 5:72-81.

4. Morren, C. and J. Decaisne. Observations on the Xore of Japan followed by the monograph of the genus Epimedium. Annals of Natural Sciences Botany. 1834; 2: 347-361 [In French].

5. Decne. in Jacquem. Voy. Bot. Himal. 1844; 9:8.

6. Hook. f. and Thorns., 1855. Flora Indica. 231, Hook f., I.c. 112.

7. Stewart RR, Ann. Cat.Vas. PI. West Pakistan and Kashmir. 1972;281.

8. Arief ZM, Munshi AH, Shawl AS. Evaluation of medicinal value of Epimedium elatum on the basis of pharmacologically active constituents, Icariin and Icariside-II. Pakistan Journal of Pharmaceutical Sciences. 2015; 28(5)

9. Sofi SN, Shakeel-u-Rehman, Qazi PH, Lone SH, Bhat HM, Bhat KA. Isolation, identification, and simultaneous quantification of five major flavonoids in Epimedium elatum by high performance liquid chromatography. Journal of Liquid Chromatography \& Related Technologies. 2014; 37(8):1104-1113.

10. Naseer S, Lone SH, Lone JA, Khuroo MA, Bhat KA. LC-MS guided isolation, quantification and antioxidant evaluation of bioactive principles from Epimedium elatum. Journal of Chromatography B. 2015; 989:62-70.

11. Arief ZM, Shawl AS, Munshi AH. Altitudinal variation in pharmacologically active compounds of wild and cultivated populations of Epimedium elatum. Journal of Applied Research on Medicinal and Aromatic Plants. 2016; 3(2):48-51.

12. Chen XJ, Tang ZH, Li XW, Xie CX, Lu JJ, Wang YT. Chemical constituents, quality control, and bioactivity of epimedii folium (Yinyanghuo). The American Journal of Chinese Medicine. 2015; 43(05): 783-834.

13. Tantry MA, Dar JA, Idris A, Akbar S, Shawl AS. Acylated flavonol glycosides from Epimedium elatum, a plant endemic to the Western Himalayas. Fitoterapia. 2012; 83 (4):665-670.

14. Sajad Ahmad Lone. Molecular, Phytochemical and Cytological Characterization of Epimedium elatum (Morr \& Decne) - A Rare High Altitude Medicinal Plant of Northwestern Himalayas in India, 2018 (PhD. Thesis).

15. Ellegren H, Galtier N. Determinants of genetic diversity. Nature Reviews Genetics. 2016; 17(7):422.

16. Nag A, Ahuja PS, Sharma RK. Genetic diversity of high-elevation populations of an endangered medicinal plant. AoB Plants. 2015;7.

17. Neel M, Ellstrand N. Conservation of genetic diversity in the endangered plant Eriogonum ovalifolium var. vineum (Polygonaceae). Conservation Genetics. 2003; 4:337-352.

18. Sarwat M, Nabi G, Das S, Srivastava PS. Molecular markers in medicinal plant biotechnology: past and present. Critical reviews in biotechnology. 2012; 32(1):74-92.

19. Nakai R, Shoyama Y, Shiraishi S. Genetic characterization of Epimedium species using random amplified polymorphic DNA (RAPD) and PCR-restriction fragment length polymorphism (RFLP) diagnosis. Biological and Pharmaceutical Bulletin. 1996; 19(1):67-70.

20. Lim JD, Seong ES, Choi KJ, Kim SK, Chung IM, Heo K, Yu CY. Morphological characteristics and RAPD analysis of Epimedium spp. Korean Journal of Medicinal Crop Science. 2000; 8(2):102-8.
21. Ming Feng Du. (2008). DNA Genetic Diversity of Genus Epimedium L. and Its Phylogeny. Guizhou Normal University, Master Thesis, China [In Chinese].

22. Li MJ, Du MF, Chen QF. Study on RAPD Genetic Diversity of Genus Epimedium L. Seed. 2011; 6:014.

23. Ming-jun LI. Establishment of DNA fingerprints on Epimedium L. Journal of Anhui Agricultural Sciences. 2011;18: 037.

24. Doyle JJ, Doyle JL. A rapid procedure for DNA purification from small quantities of fresh leaf tissue. Phytochemical Bulletin. 1987; 19:11-5.

25. Porebski S, Bailey LG, Baum BR. Modification of a CTAB DNA extraction protocol for plants containing high polysaccharide and polyphenol components. Plant molecular biology reporter. 1997 15(1):8-15.

26. Alam MA, Naik PK, Mishra GP. Congruence of RAPD and ISSR markers for evaluation of genomic relationship among 28 populations of Podophyllum hexandrum Royle from Himachal Pradesh, India. Turkish Journal of Botany. 2009; 33(1):1-12.

27. Naik PK, Alam MA, Singh H, Goyal V, Parida S, Kalia S, Mohapatra T. Assessment of genetic diversity through RAPD, ISSR and AFLP markers in Podophyllum hexandrum: a medicinal herb from the Northwestern Himalayan region. Physiology and Molecular Biology of Plants. 2010; 16(2):135-148.

28. Sodagar N, Bahrami AR, Memariani F, Ejtehadi H, Vaezi J, Khosravi AR. Biosystematic study of the genus Berberis L.(Berberidaceae) in Khorassan, NE Iran. Plant systematics and evolution. 2012; 298(1):193-203.

29. Sultan P, Shawl AS, Rehman S, Ahmed SF, Ramteke PW. Molecular characterization and marker based chemotaxonomic studies of Podophyllum hexandrum Royle. Fitoterapia. 2010; 81(4):243-247.

30. Roldàn-Ruiz I, Dendauw J, Van Bockstaele E, Depicker A, De Loose MA. FLP. AFLP markers reveal high polymorphic rates in ryegrasses (Lolium spp.). Molecular breeding. 2000; 6(2):125-134.

31. Powell W, Morganate M, Andre C, Hanafey M., Vogel J, Tingey S Rafalski A. The comparison of RFLP, RAPD, AFLP and SSR (microsatellite) markers for germplasm analysis. Molecular Breeding. 1996; 2:225-238.

32. Prevost A, Wilkinson MJ. A new system of comparing PCR primers applied to ISSR fingerprinting of potato cultivars. Theoretical and Applied Genetics. 1999; 98(1):107-112

33. Rohlf M. NTSYS-pc: numerical taxonomy and multivariate analysis system. Version 2.2. Dept. of Ecology and Evolution. State University of New York. 1998.

34. Kachroo P, Singh, G. Forest flora of Srinagar and plants of neighbourhood. Bishen Singh Mahendra Pal Singh, Dehradun, India. 1976.

35. Sharma BM, Jamwal PS. Flora of Upper Liddar Valleys of Kashmir Himalaya. Scientific Publishers, Jodhpur, Rajasthan, India. 1998; 2.

36. Nybom $H$, Weising $K$, Rotter B. DNA fingerprinting in botany: past, present, future. Investigative genetics. 2014; 5(1):1

37. Lone SA, Hassan QP, Gupta S, Mushtaq S, Sultan P, Bedi YS. Morphological studies and meiotic chromosome analysis of Epimedium elatum (Morr \& Decne)-Rare endemic medicinal plant of Northwestern Himalayas in India. Current Botany. 2017; 8:81-91.

38. Catherine Brahic. Horny goat weed could be better than Viagra. DAILY NEWS 26 September 2008 (https://www.newscientist.com/article/ dn14825-horny-goat-weed-could-be-better-than-viagra). 